Makoto Tanaka $\mathrm{MD}$, *

Seiji Watanabe MD, ${ }^{\dagger}$

Naoki Matsumiya MD, *

Minako Okada MD, *

Tsukasa Kondo MD, *

Shinji Takahashi $\mathrm{MD}^{*}$

\section{Enhanced pain management for post- gastrectomy patients with combined epidural morphine and fentanyl}

Purpose: To determine whether clinical advantages could be demonstrated by epidural fentanyl given in addition to epidural morphine for postgastrectomy analgesia.

Methods: One-hundred and twenty two patients undergoing elective gastrectomy were prospectively studied in a randomised, double-blind fashion. All patients received epidural lidocaine $1.5 \%$ with epinephrine $(1: 200,000)$ followed by light general anaesthesia for surgical anaesthesia. They were assigned to four groups according to the combinations of each epidural opioid: $2 \mathrm{mg}$ morphine alone, $2 \mathrm{mg}$ morphine $+100 \mu \mathrm{g}$ fentanyl, $4 \mathrm{mg}$ morphine alone, and $4 \mathrm{mg}$ morphine $+100 \mu \mathrm{g}$ fentanyl. Morphine and fentanyl were given epidurally approximately 60 and $15 \mathrm{~min}$, respectively, before the completion of surgery.

Results: Addition of epidural fentanyl to both doses of morphine not only decreased intensity of pain associated with coughing during the early postoperative period, but also prolonged the time until the first analgesic request at each morphine dose studied. Of the combination doses, $4 \mathrm{mg}$ morphine $+100 \mu \mathrm{g}$ fentanyl provided the longest time to the first request for analgesic, and was associated with least amount of postoperative analgesic supplement and best patient satisfaction without increasing incidence of side effects.

Conclusion: The addition of $100 \mu \mathrm{g}$ fentanyl to $2 \mathrm{mg}$ or $4 \mathrm{mg}$ epidural morphine provides clinical advantages over morphine alone for post-gastrectomy analgesia.

Objectif : Déterminer s'il est cliniquement avantageux d'ajouter du fentanyl à la morphine épidurale pour procurer l'analgésie après une gastrectomie.

Méthodes : Cent vingt-deux patients programmés pour une gastrectomie non urgente ont participé à cette étude aléatoire en double aveugle. Pour l'intervention, tous les patients ont reçu une épidurale à la lidocaine $1,5 \%$ adrénalinée $(1: 200,000)$ suivie d'une anesthésie générale légère. Les patients étaient répartis en quatre groupes déterminés par le mode d'administration des morphiniques: morphine seule $2 \mathrm{mg}$, morphine $2 \mathrm{mg}+$ fentanyl $100 \mu \mathrm{g}$, morphine $4 \mathrm{mg}$ seule, et morphine $4 \mathrm{mg}+$ fentany $100 \mu \mathrm{g}$. La morphine et le fentanyl ont été administrés par la voie épidurale environ 60 et 15 min avant la complétion de la chirurgie.

Résultats : Non seulement l'ajout de fentanyl épidural aux deux doses de morphine diminuait l'intensité de la douleur associée à la toux de la période postopératoire immédiate mais prolongeait de plus l'intervalle précédant la première demande d'analgésique avec chacune des doses de morphine. Cette prolongation était la plus marquée avec morphine $4 \mathrm{mg}+$ fentanyl $100 \mu \mathrm{g}$. Cette dermière combinaison est celle qui nécessitait le moins de supplément analgésique et procurait le plus haut degré de satisfaction chez le patient sans augmenter les effets secondaires.

Conclusion : Il est cliniquement avantageux d'ajouter du fentanyl à la morphine épidurale pour l'analgésie après une gastrectomie.

From the "Department of Anaesthesia/Critical Care Medicine, Tsuchiura Kyodo General Hospital, Ibaraki, Japan and ${ }^{\dagger}$ Mito Saiseikai General Hospital, Ibaraki, Japan.

Address correspondence to: Dr. Makoto Tanaka, Department of Anaesthesia, Akita University, School of Medicine, 1-1-1 Hondo, Akita-shi, Akita-ken 010, Japan; Phone: 81-188-33-1166; Fax: 81-188-36-5248.

Accepted for publication June 21, 1997. 
S TUDIES on postoperative analgesia using epidural combinations of morphine and fentanyl have shown conflicting results. ${ }^{1-4}$ Epidural administration of fentanyl during Caesarean section followed by morphine resulted in either inferior ${ }^{1}$ or no improvement ${ }^{2}$ in postoperative analgesia compared with epidural morphine alone. On the other hand, epidural fentanyl given after morphine improved post-hysterectomy analgesia without increasing adverse side effects. ${ }^{3,4}$ Not only the mode of study (prospective ${ }^{2-4}$ vs retrospective ${ }^{1}$ ) and the sequence of opioid administration (fentanyl before ${ }^{1,2}$ or after morphine ${ }^{3,4}$ ) differed among these studies, but the analgesic efficacy of such opioid combinations also seems to be affected by the type of surgery studied. In other words, beneficial effects appeared to be demonstrated more clearly following more invasive procedures such as radical abdominal hysterectomy than after less invasive procedures such as Caesarean section.

To address these issues further, we conducted this prospective, randomised, double-blind study to determine whether the addition of fentanyl improved postoperative analgesia compared with epidural morphine alone after gastrectomy.

\section{Methods}

The protocol was approved by our Institutional Research Committee Involving Human Subjects and informed consent was obtained from each patient. One-hundred and twenty two patients, ASA physical status I or II, scheduled for elective partial gastrectomy or total gastrectomy due to malignant disease were studied. Patients with a history of diabetes, neurological disorders, or those receiving analgesic medication preoperatively were not included.

The anaesthetic technique was standardized as follows: All patients received premedication with 5 or 10 $\mathrm{mg}$ diazepam and $20 \mathrm{mg}$ famotidine $p o 90 \mathrm{~min}$ before induction of anaesthesia. After an epidural catheter was placed at either $\mathrm{T}_{7-8}$ or $\mathrm{T}_{8-9}$ interspace using a loss of resistance technique, surgical anaesthesia was obtained by initially injecting $15 \mathrm{ml}$ lidocaine $1.5 \%$ with epinephrine $(1: 200,000)$ after a negative test dose response using $3 \mathrm{ml}$ of the same solution. If sensory analgesia, determined by a pin-prick method, was below $\mathrm{T}_{4} 20 \mathrm{~min}$ after injection, a $5 \mathrm{ml}$ increment of the same solution was injected epidurally to ascertain $\mathrm{T}_{4}$ analgesia or above bilaterally in all the patients. General anaesthesia was then induced with $5 \mathrm{mg} \cdot \mathrm{kg}^{-1}$ thiamylal and muscle relaxation was produced with $0.2 \mathrm{mg} \cdot \mathrm{kg}^{-1}$ vecuronium $i v$. The trachea was intubated in all the patients, and anaesthesia was maintained with nitrous oxide $50-67 \%$, oxygen, and end-tidal isoflurane $0-0.5 \%$. Incremental epidural lidocaine was given as one half of the initial dose either hourly or when systolic blood pressure (SBP) increased by $20 \%$ above the preinduction value. No additional dose was given during the last $90 \mathrm{~min}$ of surgery. End-tidal $\mathrm{CO}_{2}$ was maintained at $4-4.7 \mathrm{kPa}$ throughout the surgery. Arterial hypotension and bradycardia were treated using ephedrine and atropine $i v$, respectively.

Each consecutive patient was assigned into one of the four groups using a computerised-random number according to the dose of narcotics as follows; $\mathrm{M}_{2} \mathrm{~F}_{0}$ group ( $2 \mathrm{mg}$ morphine + no fentanyl, $\mathrm{n}=3 \mathrm{l}), \mathrm{M}_{2} \mathrm{~F}_{100}$ group ( $2 \mathrm{mg}$ morphine $+100 \mu \mathrm{g}$ fentanyl, $\mathbf{n}=30$ ), $\mathrm{M}_{4} \mathrm{~F}_{0}$ group (4 mg morphine + no fentanyl, $\mathrm{n}=31$ ), and $\mathrm{M}_{4} \mathrm{~F}_{100}$ group ( $4 \mathrm{mg}$ morphine $+100 \mu \mathrm{g}$ fentanyl, $\mathrm{n}=30$ ). Morphine hydrochloride diluted in $10 \mathrm{ml}$ normal saline was injected epidurally approximately $60 \mathrm{~min}$ before completion of surgery. Fentanyl diluted in $10 \mathrm{ml}$ normal saline was injected epidurally when the surgeon started to close the peritoneum. ${ }^{5}$ For those who received morphine alone, saline $10 \mathrm{ml}$ was injected at this time. Study drugs were prepared by the hospital pharmacy, coded, and blinded to patients, investigators and nurses involved in the care of the patients or the collection of data. At the completion of surgery, residual neuromuscular blockade was reversed with 0.02 $\mathrm{mg} \cdot \mathrm{kg}^{-1}$ atropine and $0.05-0.07 \mathrm{mg} \cdot \mathrm{kg}^{-1}$ neostigmine before endotracheal extubation. After extubation, respiratory rate and arterial blood gas tensions were measured in the operating room while patients were spontaneously breathing and were undisturbed.

After returning to the recovery room, the following variables were recorded by nurses specially trained for pain investigations using a $10 \mathrm{~cm}$ visual analog pain scale at rest (VAS: immediately after, and then in each period of 1-2, 2-3, 3-6, 6-12, 12-18, and 18-24 hr after surgery), and after a forceful cough at the similar intervals. The time from the end of surgery until the first request of supplemental analgesic, and analgesic requirement (defined as the total number of unit dose of buprenorphine, $0.2 \mathrm{mg}$ intramuscularly, within the first $24 \mathrm{hr}$ ) were recorded. If multiple VAS scores were obtained during each period, the maximum value was used for statistical analysis. If patients requested no analgesic within the first $48 \mathrm{hr}$, the time until the first analgesic request was regarded as $48 \mathrm{hr}$ for the purpose of data analysis. A unit buprenorphine dose was given within 10 min of patient's request, and was repeated if satisfactory pain relief was not obtained within the next 30 min. If VAS scores remained $>6$ despite two consecutive doses of buprenorphine, the patients were to be excluded from the study and were to receive other analgesics such as diclofenac sodium suppositories. The presence 
and severity of nausea and vomiting were specifically asked and assessed by a nausea score: 0 , no nausea; 1 , mild nausea but no vomiting; 2 , nausea easily relieved by vomiting and requiring no treatment; 3 , intractable vomiting requiring treatment. Metoclopramide $10 \mathrm{mg}$ was given, for intractable vomiting, by iv bolus on patient requests. Presence of pruritus were also specifcally asked by the nurses. All patients received 5 litre $\cdot \mathrm{min}^{-1}$ oxygen via a face mask, and oxygen saturation was monitored continuously by a pulse oximeter for 24 hr after surgery. Respiratory rate was monitored every 15 min during the first four hours, and then hourly for the following $20 \mathrm{hr}$. Respiratory depression was defined as respiratory rate $<10$ breaths $\mathrm{min}^{-1}$ or oxygen saturation $<95 \%$ by pulse oximeter. Urinary retention was not assessed because all patients had indwelling urinary catheters. At the end of $24 \mathrm{hr}$, all patients were interviewed by a blinded observer to evaluate their overall satisfaction in postoperative analgesic regimen graded as; excellent, good, fair, or poor.

Results are expressed as mean $\pm \mathrm{SD}$. Comparisons of demographic data, time to the first analgesic request, analgesic requirement, postoperative respiratory rate and arterial $\mathrm{CO}_{2}$ tensions were performed using unpaired Student's $t$ test with Bonferroni's correction to adjust for multiple comparisons. Differences in median VAS scores were analysed using Mann-Whitney $U$ test between groups. Chi-squared analysis of contingency table was used for comparisons of patient satisfaction, and incidence and severity of side effects. A $P$ value of $<0.05$ was considered statistically significant.

\section{Results}

Demographic and intraoperative data were comparable among groups (Table I). No patient was excluded from the study because of inadequate pain relief by buprenorphine.

Postoperative VAS scores at rest in the $\mathrm{M}_{4} \mathrm{~F}_{100}$ group were less than those in the $\mathrm{M}_{4} \mathrm{~F}_{0}$ and the $\mathrm{M}_{2} \mathrm{~F}_{0}$ groups during the early postoperative period, while the $M_{2} F_{100}$ group showed lower VAS scores than the $\mathrm{M}_{4} \mathrm{~F}_{0}$ group during $1-2 \mathrm{hr}$ after surgery $(P<0.05$, Figure 1). The VAS scores in the $\mathrm{M}_{4} \mathrm{~F}_{0}$ and $\mathrm{M}_{4} \mathrm{~F}_{100}$ groups were less than those in the $M_{2} F_{0}$ group from 12 to $24 \mathrm{hr}$ after surgery $(P<0.05$, Figure 1$)$. The effects of adding fentanyl to epidural morphine were more remarkable on VAS scores with forceful coughing than those at rest. Those receiving additional fentanyl to either dose of morphine $\left(\mathrm{M}_{2} \mathrm{~F}_{100}\right.$ and $\mathrm{M}_{4} \mathrm{~F}_{100}$ groups) showed lower VAS scores in the early postoperative period than did those receiving morphine alone $\left(\mathrm{M}_{2} \mathrm{~F}_{0}\right.$ and $\mathrm{M}_{4} \mathrm{~F}_{0}$ groups, $P<0.05$, Figure 2$)$. Towards the end of the study period, those receiving
TABLE I Demographic and intraoperative data

\begin{tabular}{|c|c|c|c|c|}
\hline & $\begin{array}{c}M_{2} F_{0} \\
(n=31)\end{array}$ & $\begin{array}{l}M_{2} F_{100} \\
(n=30)\end{array}$ & $\begin{array}{c}M_{4} F_{0} \\
(n=31)\end{array}$ & $\begin{array}{l}M_{4} F_{100} \\
(n=30)\end{array}$ \\
\hline Sex (male/female) & $17 / 14$ & $14 / 16$ & $15 / 16$ & $16 / 14$ \\
\hline Age (yr) & $58 \pm 10$ & $55 \pm 11$ & $57 \pm 10$ & $58 \pm 9$ \\
\hline Weight (kg) & $58 \pm 9$ & $58 \pm 10$ & $57 \pm 11$ & $56 \pm 10$ \\
\hline Height $(\mathrm{cm})$ & $158 \pm 10$ & $162 \pm 11$ & $159 \pm 9$ & $160 \pm 8$ \\
\hline $\begin{array}{l}\text { Partial gastrectomy/ } \\
\text { total gastrectomy }\end{array}$ & $24 / 7$ & $22 / 8$ & $22 / 9$ & $23 / 7$ \\
\hline $\begin{array}{l}\text { Epidural morphine } \\
\text { administration to } \\
\text { the end of } \\
\text { surgery (min) }\end{array}$ & $59 \pm 16$ & $65 \pm 18$ & $62 \pm 20$ & $57 \pm 21$ \\
\hline $\begin{array}{l}\text { Duration of } \\
\text { surgery (min) }\end{array}$ & $215 \pm 31$ & $223 \pm 76$ & $223 \pm 56$ & $205 \pm 61$ \\
\hline $\begin{array}{l}\text { Estimated blood } \\
\text { loss }(\mathrm{ml})\end{array}$ & $345 \pm 158$ & $341 \pm 189$ & $360 \pm 178$ & $396 \pm 166$ \\
\hline $\begin{array}{l}\text { Total lidocaine } \\
\text { dose }\left(\mathrm{mg}^{\circ} \mathrm{kg}^{-1}\right)\end{array}$ & $7.8 \pm 1.7$ & $7.6 \pm 2.6$ & $8.3 \pm 2.4$ & $7.6 \pm 2.3$ \\
\hline
\end{tabular}

Values are mean \pm SD or number of patients. No significant differences among groups.

$\mathrm{M}_{2} \mathrm{~F}_{0}=2 \mathrm{mg}$ morphine alone;

$\mathrm{M}_{2} \mathrm{~F}_{100}=2 \mathrm{mg}$ morphine, $100 \mu \mathrm{g}$ fentanyl;

$\mathrm{M}_{4} \mathrm{~F}_{0}=4 \mathrm{mg}$ morphine alone;

$\mathrm{M}_{4} \mathrm{~F}_{100}=4 \mathrm{mg}$ morphine, $100 \mu \mathrm{g}$ fentanyl.

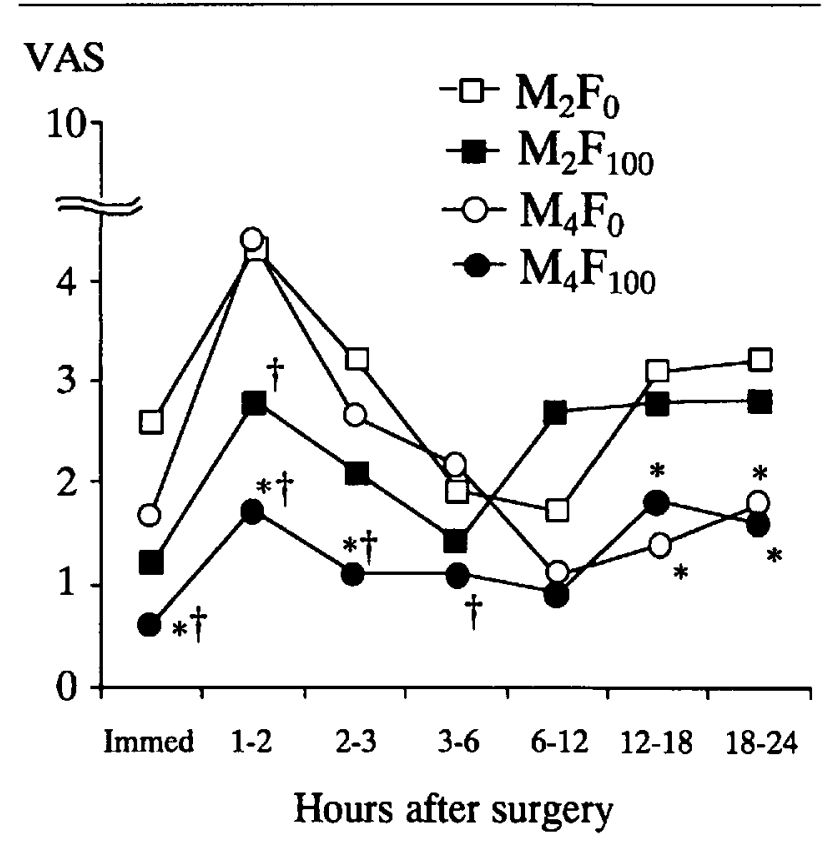

FIGURE I Median visual analog pain scale (VAS) scores at rest after gastrectomy.

${ }^{\star} P<0.05$ vs the $\mathrm{M}_{2} \mathrm{~F}_{0}$ group. ${ }^{\dagger} P<0.05$ vs the $\mathrm{M}_{4} \mathrm{~F}_{0}$ group.

$\mathrm{M}_{2} \mathrm{~F}_{0}=2 \mathrm{mg}$ morphine, alone $(\mathrm{n}=31)$;

$\mathrm{M}_{2} \mathrm{~F}_{100}=2 \mathrm{mg}$ morphine, $100 \mu \mathrm{g}$ fentanyl $(\mathrm{n}=30)$;

$M_{4} F_{0}=4 \mathrm{mg}$ morphine, $100 \mu \mathrm{g}$ fentanyl $(\mathrm{n}=31)$;

$\mathrm{M}_{4} \mathrm{~F}_{100}=4 \mathrm{mg}$ morphine, $100 \mu \mathrm{g}$ fentanyl $(\mathrm{n}=30)$. 


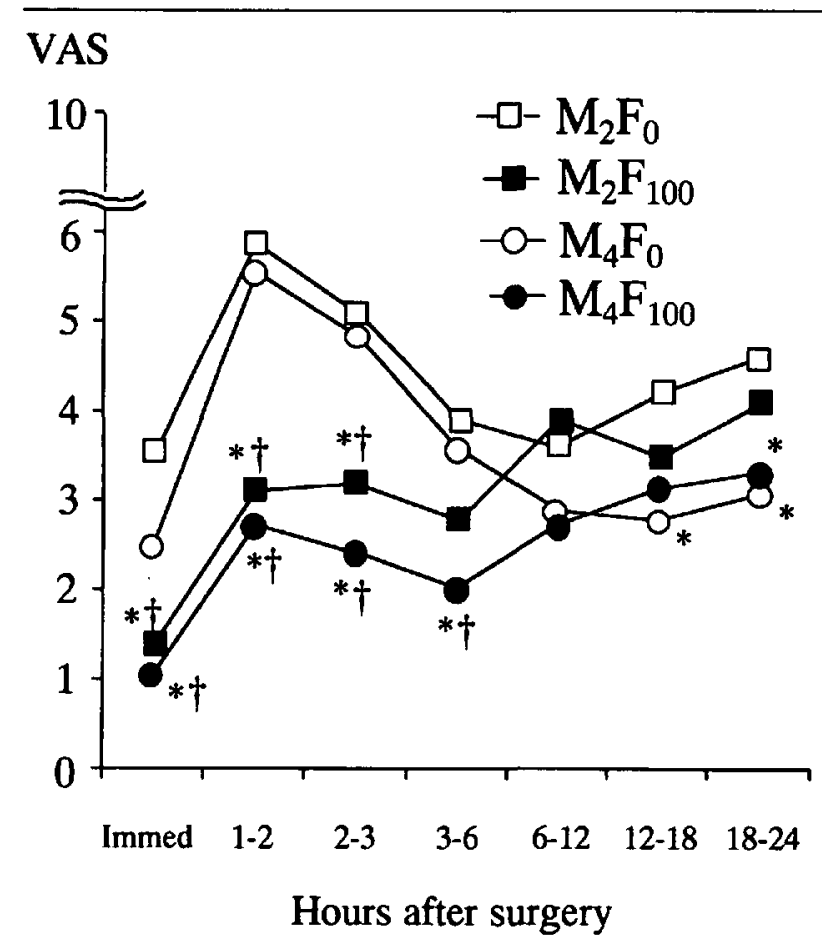

FIGURE 2 Median visual analog pain scale (VAS) scores at forceful cough after gastrectomy.

${ }^{*} P<0.05$ vs the $\mathrm{M}_{2} \mathrm{~F}_{0}$ group. ${ }^{\dagger} P<0.05$ ps the $\mathrm{M}_{4} \mathrm{~F}_{0}$ group.

$M_{2} F_{0}=2 \mathrm{mg}$ morphine alone $(n=16)$;

$M_{2} F_{100}=2 \mathrm{mg}$ morphine, $100 \mu \mathrm{g}$ fentanyl $(\mathrm{n}=15)$;

$M_{4} F_{0}=4 \mathrm{mg}$ morphine alone $(n=16)$;

$M_{4} F_{100}=4 \mathrm{mg}$ morphine, $100 \mu \mathrm{g}$ fentanyl $(\mathrm{n}=15)$.

$4 \mathrm{mg}$ morphine $\left(\mathrm{M}_{4} \mathrm{~F}_{0}\right.$ and $\mathrm{M}_{4} \mathrm{~F}_{100}$ groups) developed lower VAS scores than the $M_{2} \mathrm{~F}_{0}$ group $(P<0.05$, Figure 2). Time until the first analgesic request in the $\mathrm{M}_{4} \mathrm{~F}_{100}$ group was longer than in the other three groups, while that of the $\mathrm{M}_{2} \mathrm{~F}_{100}$ group was longer than the $\mathrm{M}_{2} \mathrm{~F}_{0}$ group $(P<0.05$, Table II). In addition, analgesic requirement was less in the $M_{4} F_{100}$ group

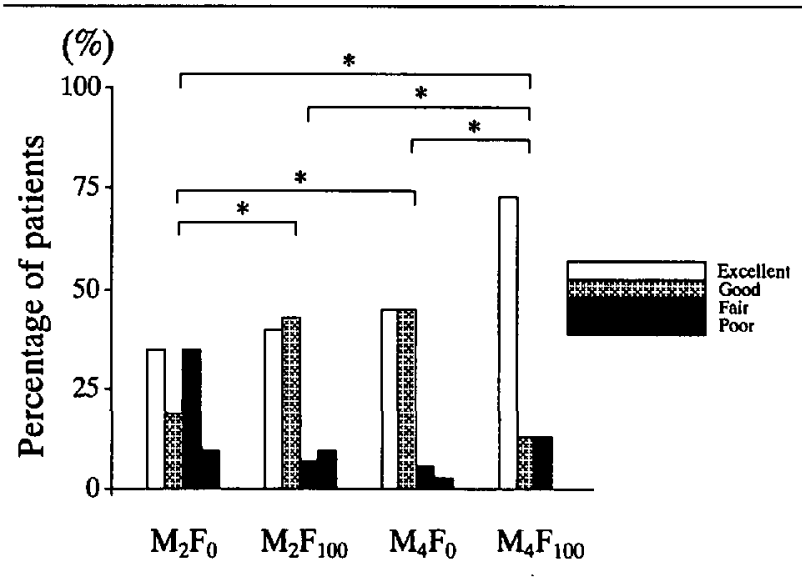

FIGURE 3 Patient overall satisfaction $24 \mathrm{hr}$ after gastrectomy surgery.

* Significant difference among groups in the proportion of patients $(P<0.05)$.

$\mathrm{M}_{2} \mathrm{~F}_{0}=$ morphine $2 \mathrm{mg}$ alone $(\mathrm{n}=31)$;

$M_{2} F_{100}=2 \mathrm{mg}$ morphine, $100 \mu \mathrm{g}$ fentanyl $(\mathrm{n}=30)$;

$M_{4} F_{0}=$ morphine $4 \mathrm{mg}$ alone $(n=31)$;

$\mathrm{M}_{4} \mathrm{~F}_{100}=4 \mathrm{mg}$ morphine, $100 \mu \mathrm{g}$ fentanyl $(\mathrm{n}=30)$.

than in the other three groups $(P<0.05$, Table II $)$. Postoperative patient satisfaction was most favourable in the $\mathrm{M}_{4} \mathrm{~F}_{100}$ group, and least favourable in the $\mathrm{M}_{2} \mathrm{~F}_{0}$ group $(P<0.05$, Figure 3$)$.

No differences were seen in respiratory rates or arterial $\mathrm{CO}_{2}$ tensions immediately after surgery or in the incidence and severity of postoperative side effects among groups (Table II). Pruritus was the most frequent complication, but were all mild and no patient required any medical treatment. Respiratory depression was detected in one patient in the $\mathrm{M}_{2} \mathrm{~F}_{100}$ group, and one in the $\mathrm{M}_{4} \mathrm{~F}_{0}$ group, four and seven hours after surgery, respectively. In the former, the respiratory rate was 9 breaths $\mathrm{min}^{-1}$, but $\mathrm{SpO}_{2}$ was $99 \%$ with supplemental oxygen. The latter

TABLE II Duration of analgesia, analgesic requirement, respiratory variables, and incidence of side effects

\begin{tabular}{lcccc}
\hline & $M_{2} F_{0}$ & $M_{2} F_{100}$ & $M_{4} F_{0}$ & $M_{4} F_{100}$ \\
\hline Time to first analgesic request $(\mathrm{hr})$ & $10 \pm 11$ & $20 \pm 14^{\dagger}$ & $15 \pm 12$ & $31 \pm 13^{*}$ \\
Analgesic requirement $(\mathrm{n}$-doses) & $1.5 \pm 1.0$ & $1.3 \pm 1.4$ & $1.2 \pm 0.9$ & $0.4 \pm 0.7^{*}$ \\
Respiratory variables & $17 \pm 4$ & $17 \pm 3$ & $20 \pm 4$ & $20 \pm 4$ \\
Respiratory rate (breaths $\left.\cdot \mathrm{min}^{-1}\right)$ & $5.9 \pm 0.6$ & $5.7 \pm 0.4$ & $5.9 \pm 0.4$ & $6.1 \pm 0.6$ \\
PaCO $(\mathrm{kPa})$ & $27 / 4 / 0 / 0$ & $25 / 4 / 1 / 0$ & $27 / 2 / 2 / 0$ & $28 / 2 / 0 / 0$ \\
Incidence of side cffects & $5(16)$ & $7(23)$ & $8(26)$ & $9(30)$ \\
Nausea Score $(0 / 1 / 2 / 3)$ & $0(0)$ & $1(3)$ & $1(3)$ & $0(0)$ \\
Pruritus & & & \\
Respiratory depression & & &
\end{tabular}

Values: Mean \pm SD or number of patients (percentages).

${ }^{\star} P<0.05$ vs the other three groups. ${ }^{\dagger} P<0.05$ vs $\mathrm{M}_{2} \mathrm{~F}_{0}$. 
patient developed a respiratory rate of 8 breaths $\mathrm{min}^{-1}$, with $\mathrm{SpO}_{2}$ of $99 \%$ with oxygen. Both patients were easily arousable by verbal commands, relatively comfortable with VAS scores $<3$ at rest, and no further treatment was necessary.

\section{Discussion}

Improved patient satisfaction and reduced suffering from pain seen in our study is the major justification for the use of opioid combination regimens. ${ }^{6}$ Such a combination with a higher dose of morphine $(4 \mathrm{mg})$ not only prolonged the duration of analgesia, but also reduced postoperative analgesic requirement without increasing the incidence and severity of side effects compared with smaller opioid doses. Of the combination doses in the present study, $4 \mathrm{mg}$ morphine +100 $\mu \mathrm{g}$ fentanyl appears to be the minimum effective combination for post-gastrectomy analgesia. However, it remains to be determined whether smaller combination doses, such as $3 \mathrm{mg}$ morphine $+100 \mu \mathrm{g}$ or $50 \mu \mathrm{g}$ fentanyl, produce a similar analgesic profile. In addition, whether a larger combination dose of epidural morphine and fentanyl than in the present combination can augment analgesia profile without adversely increasing incidence of side effects is open for question.

Our previous study in post-hysterectomy analgesia using the same opioid combination demonstrated that $2 \mathrm{mg}$ morphine $+50 \mu \mathrm{g}$ fentanyl was the minimum effective combination dose. ${ }^{4}$ The results of the present study agree with respect to the beneficial effect of adding fentanyl to epidural morphine after major abdominal surgery, but disagree in that a larger combination dose was required to obtain a similar analgesia profile after gastrectomy than after hysterectomy. However, direct comparison may be difficult since different surgical sites and patient populations were involved. In another study examining postoperative analgesia after major gynaecological procedures, approximately $20 \%$ of patients receiving $4 \mathrm{mg}$ epidural morphine alone requested supplemental analgesics within four hours after surgery, while patients receiving $4 \mathrm{mg}$ morphine $+100 \mu \mathrm{g}$ fentanyl combination required no further analgesics within $17 \mathrm{hr}$ after surgery. ${ }^{3}$ In the present study, the proportion of patients requiring supplemental analgesic during the first four hours after surgery in the $\mathrm{M}_{4} \mathrm{~F}_{100}$ group (10\%) was considerably less than those in the $M_{2} F_{0}$ (50\%) and $\mathrm{M}_{4} \mathrm{~F}_{0}(35 \%)$ groups. This is likely due to the lower VAS scores both at rest and at movement in the $\mathrm{M}_{4} \mathrm{~F}_{100}$ group than those in the $\mathrm{M}_{2} \mathrm{~F}_{0}$ and $\mathrm{M}_{4} \mathrm{~F}_{0}$ groups during the early postoperative period. Highly lipophilic opioids such as fentanyl in our study as well as sufentanil in a previous report ${ }^{7}$ exerted analgesic effect rapidly, eliminated early inadequacy of analgesia from epidural morphine alone, ${ }^{8}$ and thereby reduced the proportion of patients in pain requiring analgesic supplement. The beneficial effect of additional fentanyl, however, becomes obscured approximately 12 hr after surgery (Figures 1 and 2). Rather, patients receiving $4 \mathrm{mg}$ morphine with or without fentanyl tended to demonstrate lower VAS scores towards the end of the study period than those receiving $2 \mathrm{mg}$ morphine. These observations suggest that, in our regimen, the analgesic effect of epidural fentanyl predominates during the early postoperative period, while epidural morphine predominantly exerts analgesic effect after fentanyl wears off.

The mechanism of prolongation of the time to the first request for supplemental analgesia by the addition of fentanyl to morphine $\left(\mathrm{M}_{4} \mathrm{~F}_{100}\right.$ and $\mathrm{M}_{2} \mathrm{~F}_{100}$ groups) compared with those with morphine alone $\left(\mathrm{M}_{4} \mathrm{~F}_{0}\right.$ and $\mathrm{M}_{2} \mathrm{~F}_{0}$ groups) is not clear from our study. In the rats, however, Furst studied the synergistic interaction of morphine and fentanyl, and found a remarkable prolongation of antinociceptive action. ${ }^{9}$ Whether potential interaction of opioid combinations exists at the receptor site in humans remains to be determined.

There is rapid vascular uptake of morphine from the epidural space, and the peak plasma concentration occurs $10 \mathrm{~min}$ after administration. ${ }^{10}$ Peak plasma concentrations of morphine are known to exceed minimum effective plasma concentration and exert systemic analgesia when doses $>6$ or $10 \mathrm{mg}$ of morphine are injected epidurally, but not with $<4 \mathrm{mg}^{10-13}$ Clinical observations demonstrated that epidural 10 mg morphine is associated with a more rapid onset of analgesia ( $<30 \mathrm{~min})^{10}$ than the two to six hour latency with 4 or $5 \mathrm{mg}$ epidural morphine. ${ }^{7,12}$ The results of these reports suggest that the early onset of analgesia following relatively large doses of epidural morphine is primarily a result of systemic action which may be minimum with a small single dose of epidural morphine as demonstrated by a long latency of spinal analgesia such as seen in our study. On the other hand, vascular uptake of highly lipophilic opioid such as fentanyl given epidurally is variable. ${ }^{14}$ Even though no difference was seen in plasma fentanyl concentrations between epidural and intravenous administrations after continuous infusions of $>18 \mathrm{hr},{ }^{15,16}$ a small single dose of epidural fentanyl exerts analgesia with plasma concentration < the minimum effective concentration, suggesting a spinal mode of analgesic action. ${ }^{14}$ Based on these considerations, pharmacodynamic synergy, i.e., analgesic interaction, of single small doses of epidural morphine and fentanyl seen in our study are likely to have taken place at the spinal cord. 
Postoperative analgesic consumption in our study was not assessed by patient-controlled analgesia, which could have determined the true analgesic requirement in a more titratable manner than by im injections. However, previous studies demonstrated that total analgesic consumption after major abdominal surgery is not affected by patient-controlled $i v$ morphine analgesia compared with im morphine given on a $p r n$ basis $^{17}$ or even at fixed time intervals. ${ }^{18}$ In addition, we set up a relatively small unit buprenorphine dose, and injected it without delay in the nurses' response to the request for analgesia. A possible antagonistic effect of buprenorphine as a partial agonist of $\mu$-receptor was not seen in our study since all patients receiving buprenorphine experienced noticeable pain relief soon after $i m$ injections.

In conclusion, our data indicate that additional 100 $\mu \mathrm{g}$ fentanyl given after epidural morphine improves the quality of early postoperative analgesia, and prolongs the duration of analgesia compared with epidural morphine alone without altering incidence of side effects. Under the circumstance of our study protocol and of the combination doses studied, the minimum effective combination dose seems to be $4 \mathrm{mg}$ morphine +100 $\mu \mathrm{g}$ fentanyl for post-gastrectomy analgesia.

\section{References}

1 Cohen SE, Subak LL, Brose WG, Halpern J. Analgesia after cesarean delivery: patient evaluations and costs of five opioid techniques. Reg Anesth 1991; 16: 141-9.

2 Vincent RD Jr, Chestnut DH, Choi WW, Ostman PLG, Bates $J N$. Does epidural fentanyl decrease the efficacy of epidural morphine after cesarean delivery? Anesth Analg 1992; 74: 658-63.

3 Tanaka $M$, Watanabe $S$, Endo $T$, Okane $M$, Hamaya $Y$. Combination of epidural morphine and fentanyl for postoperative analgesia. Reg Anesth 1991 ; 16: 214-7.

4 Tanaka $M$, Watanabe S, Ashimura $H$, et al. Minimum effective combination dose of epidural morphine and fentanyl for post-hysterectomy analgesia: a randomized, prospective, double-blind study. Anesth Analg 1993; 77: 942-6.

5 Birnbach DJ, Johnson MD, Arcario T, Datta S, Naulty $J S$, Ostbeimer $G W$. Effect of diluent volume on analgesia produced by epidural fentanyl. Anesth Analg 1989; 68: 808-10.

6 Anonymous. Analgesia and the metabolic response to surgery (Editorial). Lancet 1985; I: 1018-9.

7 Sinatra RS, Sevarino FB, Chung JH, et al. Comparison of epidurally administered sufentanil, morphine, and sufentanil-morphine combination for postoperative analgesia. Anesth Analg 1991; 72: 522-7.

8 Cousins MJ, Mather LE. Intrathecal and epidural administration of opioids. Anesthesiology 1984; 61: 276-310.
9 Furst S. Pharmacological interaction of opiates with various classes of centrally acting dopaminergic drugs. Drug Metabol Drug Interact 1991; 9: 77-102.

10 Gourlay GK, Cherry DA, Cousins MJ. Cephalad migration of morphine in CSF following lumbar epidural administration in patients with cancer pain. Pain 1985; 23: 317-26.

11 Nordberg $G$, Hedner $T$, Mellstrand $T$, Borg $L$. Pharmacokinetics of epidural morphine in man. Eur $\mathbf{J}$ Clin Pharmacol 1984; 26: 233-7.

12 Youngstrom PC, Cowan RI, Sutheimer C, Eastwood $D W, \Upsilon_{u} J C$. Pain relief and plasma concentrations from epidural and intramuscular morphine in post-cesarean patients. Anesthesiology 1982; 57: 404-9.

13 Rawal N, Sjostrand U, Dablstrom B. Postoperative pain relief by epidural morphine. Anesth Analg 1981; 60: 726-31.

14 Gourlay GK, Murpby TM, Plummer JL, Kowalski SR, Cherry DA, Cousins MJ. Pharmacokinetics of fentanyl in lumbar and cervical CSF following lumbar cpidural and intravenous administration. Pain 1989; 38: 253-9.

15 Loper KA, Ready LB, Downey $M$, et al. Epidural and intravenous fentanyl infusions are clinically equivalent after knee surgery. Anesth Analg 1990; 70: 72-5.

16 Ellis DJ, Millar WL, Reisner LS. A randomized double-blind comparison of epidural versus intravenous fentanyl infusion for analgesia after cesarean section. Anesthesiology 1990; 72: 981-6.

17 Wasylak TJ, Abbott FV, English MJM, Jeans ME. Reduction of postoperative morbidity following patientcontrolled morphine. Can J Anaesth 1990; 37: 726-31.

18 Chan VWS, Chung F, McQuestion M, Gomez M. Impact of patient-controlled analgesia on required nursing time and duration of postoperative recovery. Reg Anesth 1995; 20 : 506-14. 